\title{
Manajemen Perencanaan Strategis Sistem Informasi Menggunakan Metode Tozer (Studi Kasus: SMK Bina Nusantara Ungaran)
}

\author{
Herry Sanoto \\ herry.sanoto@uksw.edu \\ Fakultas Keguruan dan Ilmu Pendidikan, Universitas Kristen Satya Wacana \\ Management Information Systems Stratgic Planning Using The Tozer Method \\ (Case Study: SMK Bina Nusantara Ungaran)
}

\begin{abstract}
Business competition in this fast-paced information age has become very tight. especially in the field of education. Thus the organization must have a business strategy that is very mature in order to face the competition. The application of information systems and technology has become one of the most influential business strategies for staying in competition. Bina Nusantara Ungaran Vocational School has implemented an information system and technology, but apparently it has not run optimally because some parts have not yet implemented an information system. In this study discusses how to plan an IS / IT strategy using the Tozer version method with supporting analysis such as Value Chain Porter's, Five Force Porter's, SWOT, Critical Success Factor, and McFarlan's Strategic Grid. Which produces a portfolio of SI / IT that is aligned with the vision and mission to support the business processes that are run and make Bina Nusantara Ungaran Vocational School excel in field of education.
\end{abstract}

Keywords: IS/IT Strategic Planning, Tozer Methodology, Value Chain, McFarlan's Strategic Grid

$\begin{array}{ccc}\text { Article Info } & \text { Received date: } 13 \text { Desember } 2020 \quad \text { Revised date: } 13 \text { Januari } 2021 \quad \text { Accepted date: } 19 \text { Januari } 2021\end{array}$

\section{PENDAHULUAN}

Pada era informasi yang begitu cepat saat ini, setiap organisasi dituntut untuk dapat bersaing serta berinovasi dalam rangka meningkatkan keuntungan sebuah organisasi. Dengan demikian organisasi berbondong-bondong menerapkan sistem informasi dan teknologi informasi agar mendapatkan proses bisnis yang berjalan secara efektif dan efisien serta memberikan nilai tambah competitive advantage dalam persaingan bisnis (Wijaya, A., \& Aliyanto, A.; 2013).. Pendidikan merupakan salah satu bisnis yang bergerak dibidang jasa tidak terlepas dari dampak globalisasi serta penggunaan sistem informasi dan teknologi informasi di proses bisnisnya. Semakin banyaknya bisnis Pendidikan dengan berbagai bentuk sangat diperlukan resources yang baik, seperti dalam halnya mempromosikan organisasinya kepada konsumen dalam hal ini adalah siswa dan orang tua.

SMK Bina Nusantara Ungaran merupakan salah satu institusi yang bergerak di bidang Pendidikan telah menerapkan sistem informasi dan teknologi informasi di proses bisnis atau operasionalnya namun belum digunakan secara maksimal, belum terintergrasi satu sama lain serta kurang selaras dengan visi misi dan strategi bisnis dari SMK Bina Nusantara Ungaran itu sendiri. Akibatnya proses bisnis atau operasional menjadi tidak efektif dan efisien.

Dalam melakukan manajemen perencanaan strategis sistem informasi ini akan digunakan metodologi Tozer, sehingga dapat dihasilkan sebuah model perencanaan strategis sistem informasi yang mendukung proses bisnis SMK Bina Nusantara serta menjawab kebutuhan SI/TI organisasi tersebut.

\section{KAJIAN PUSTAKA}

Penelitian mengenai manajemen perencanaan strategis sistem informasi dengan metodologi tozer cukup banyak dilakukan, seperti contoh pada penelitian pertama yang dilakukan oleh Andri Wijaya menyimpulkan bahwa mengidentifikasi serta menganalisa yang berhubungan maupun yang 
tidak berhubungan dengan inti bisnis perusahaan yang nantinya akan menghasilkan rekomendasi aplikasi untuk perusahaan (Wijaya, A., \& Aliyanto, A.; 2013).

Penelitian kedua yang dilakukan oleh Andri dan Arif dengan menggunakan tools Five Forces Competitive Model, McFarlan Grid, five forces competive model, analisa value chain, SWOT dan CSF (critical success factor). Yang akhirnya memiliki output yaitu portfolio aplikasi yang direncanakan guna menyelaraskan visi misi, tujuan dan proses bisnis perusahaan.

Pengertian perencanaan strategis sistem informasi menurut Ward and Pepard adalah merupakan proses mengidentifikasi kebutuhan akan aplikasi sistem informasi berbasis komputer yang nantinya mendukung organisasi dalam melaksanakan rencana bisnis serta merealisasikan tujuan bisnisnya. Perencanaan strategis sistem informasi juga menjelaskan bagaimana alat, teknik, serta kerangka kerja dalam menyelaraskan strategi SI/TI dan strategi bisnis organisasi Ward, J and Pepard Joe.

System informasi yang digunakan sebagai pendukung animasi Pendidikan harus mampu memberikan pelayanan informasi sesuai dengan kebutuhan pengguna, mudah didapatkan, sehingga berdampak pada peningkatan mutu Pendidikan (Lestari, T. A., \& Mariah, S; 2018). Dalam melakukan perencanaan strategis sistem informasi yang perlu diperhatikan adalah penggunaan metodologi. Metodologi yang digunakan adalah metodologi perencanaan strategis SI/TI versi Tozer. Dengan metodologi versi Tozer ini merupakan metodologi yang mudah dan praktis yang berdasar pada konsep strategi bisnis. Pada Gambar 1 menggambarkan tahapan perencanaan strategis SI/TI Versi Tozer (Tozer, E. E;1996).

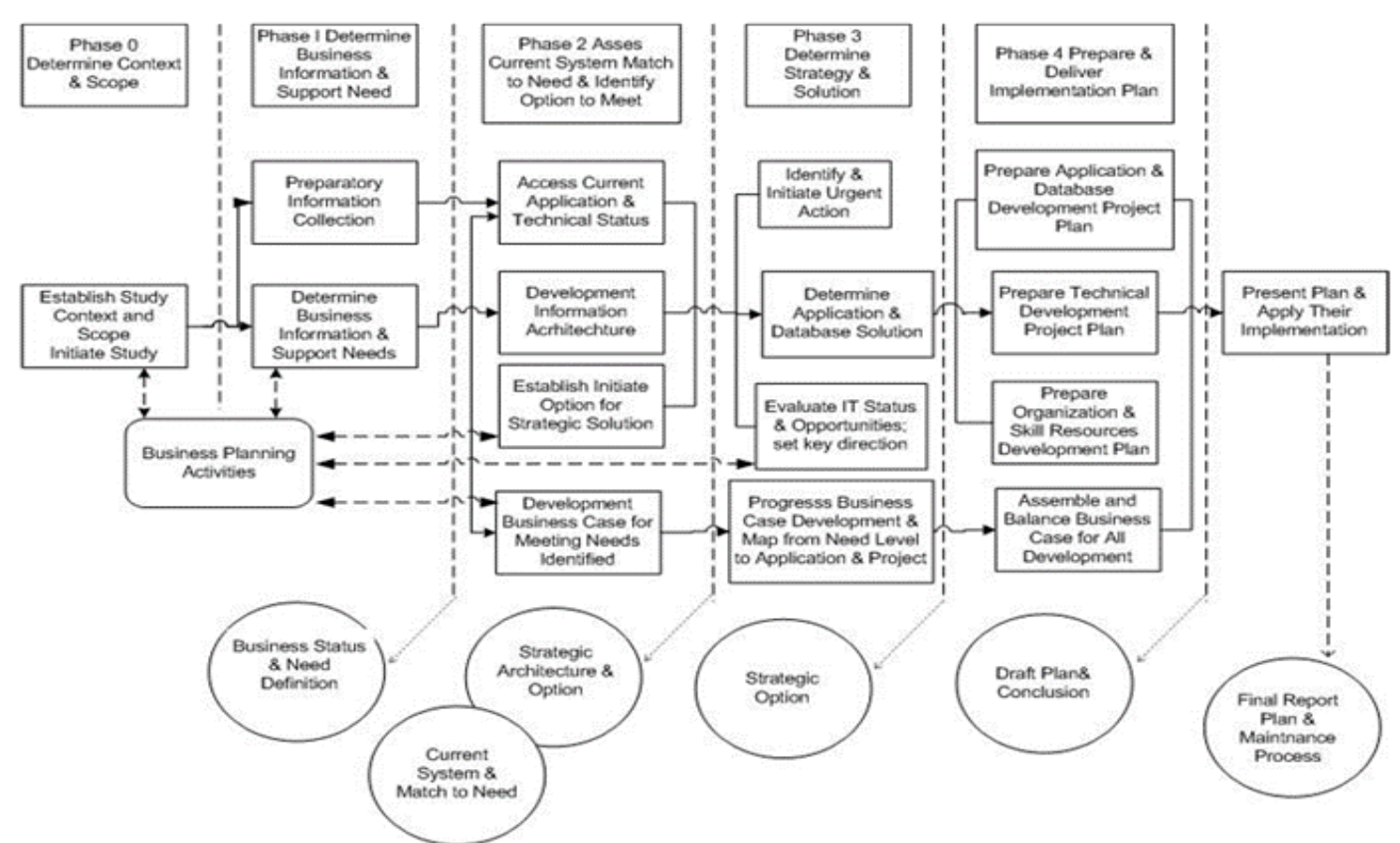

Gambar 1. Framework Perencanaan Strategis SI/TI Versi Tozer

\section{METODE PENELITIAN}

Metode penelitian yang digunakan pada penelitian ini adalah perencanaan sistem informasi versi tozer. Untuk metode pengambilan data peneliti menggunakan metode kualitatif dimana langkahlangkah yang diambil adalah berdasarkan wawancara, serta analisis lingkungan bisnis perusahaan, interpretasi data dan kesimpulan. kemudian tahapan tersebut akan menghasilkan portofolio perencanaan strategis sistem informasi. Berikut penjelasan masing-masing tahapan pada Gambar 2. 
Manajemen Perencanaan Strategis Sistem Informasi Menggunakan Metode Tozer (Studi Kasus: SMK Bina Nusantara Ungaran) (Herry Sanoto)

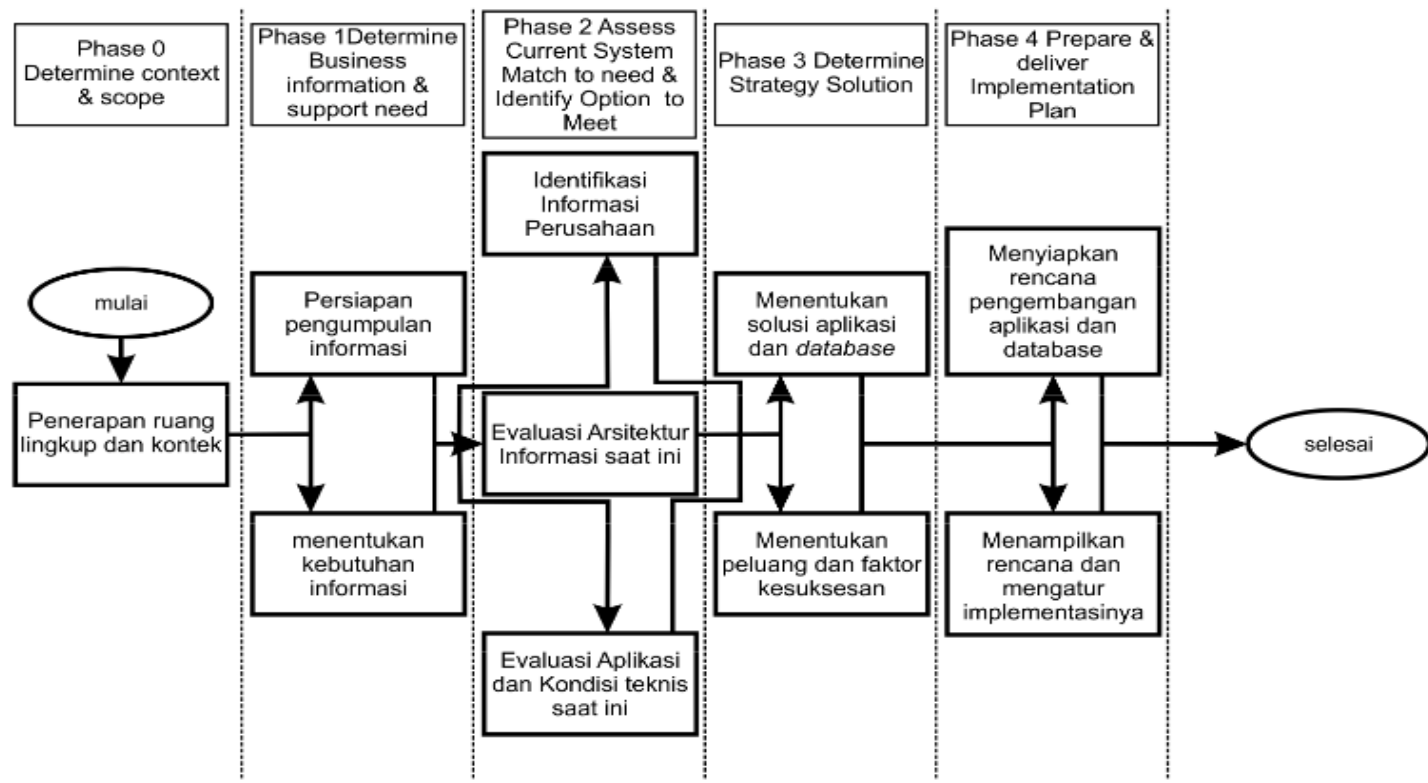

Gambar 2. Kerangka Kerja Penelitian.

\section{HASIL PENELITIAN DAN PEMBAHASAN}

Dalam pembahasan penelitian ini maka dilakukan analisis dari hasil wawancara dan observasi yang mencakup kesesuaian sistem serta kebutuhan bisnis, yang berakhir menentukan solusi atau usulan sistem informasi. Dalam menganalisa kesesuain sistem dan kebutuhan bisnis dalam penelitian ini, tools yang digunakan adalah Porter's Five Forces dan Porter's Value Chain yang sering digunakan oleh peneliti lain.

\section{Analisis Porter's Five Forces}

Fungsi dari analisa Five Forces ini adalah memetakan hal yang berasal dari eksternal organisasi yang dapat mempengaruhi jalannya proses bisnis yang memiliki dampak secara langsung maupun tidak langsung. Berikut hasil dari analisis Five Forces yang ada di SMK Bina Nusantara Ungaran pada Gambar 3.

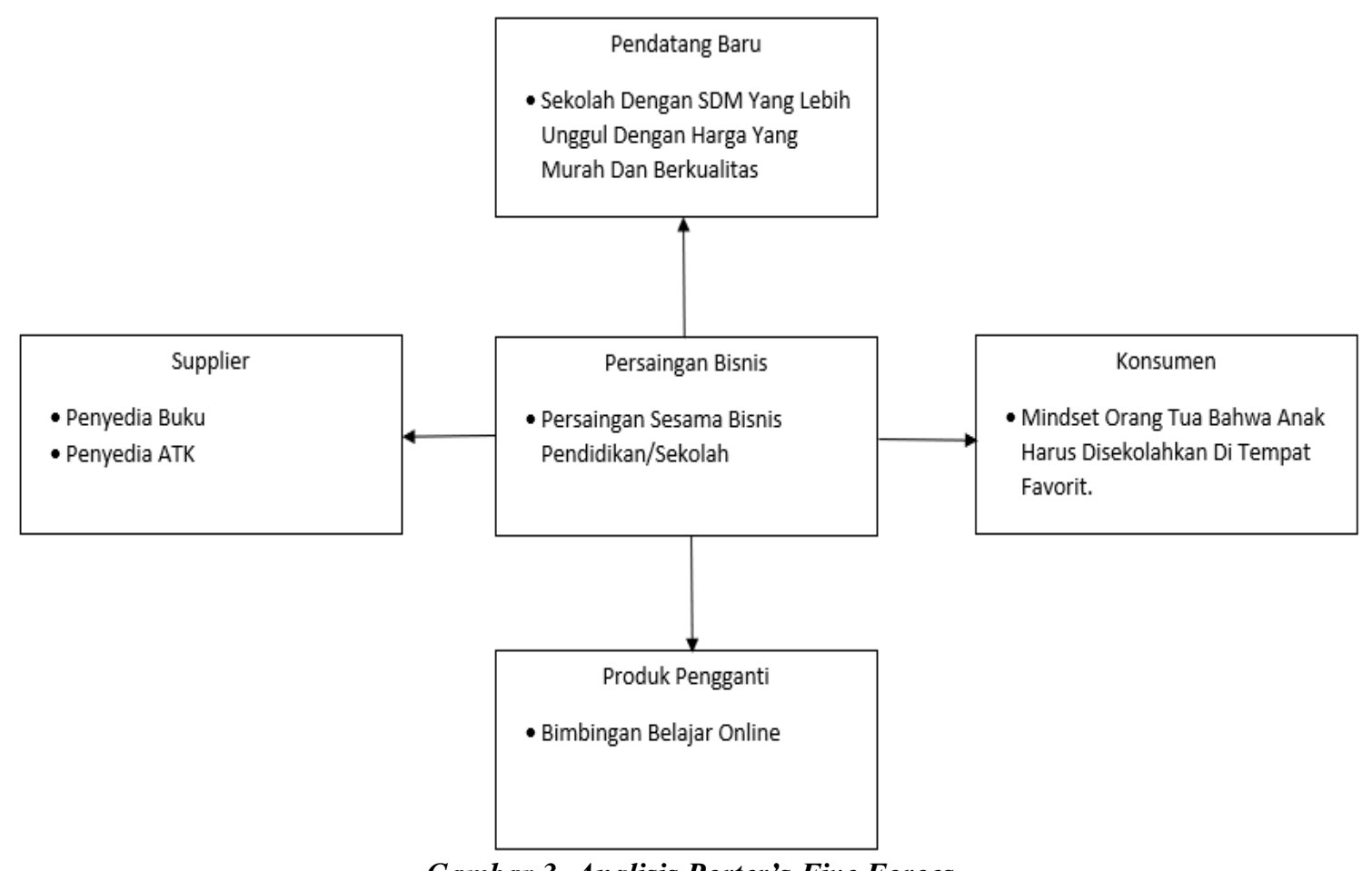

Gambar 3. Analisis Porter's Five Forces 


\section{Analisa Porter's Value Chain}

Fungsi analisa value chain ini adalah memetakan aktifitas proses bisnis internal yang dilakukan oleh organisasi SMK Bina Nusantara Ungaran baik dari aktifitas utama maupun aktifitas pendukung yang nantinya dapat mengetahui kebutuhan aplikasi untuk menunjang aktifitas tersebut. Berikut hasil analisis value chain yang terdapat pada Gambar 4.

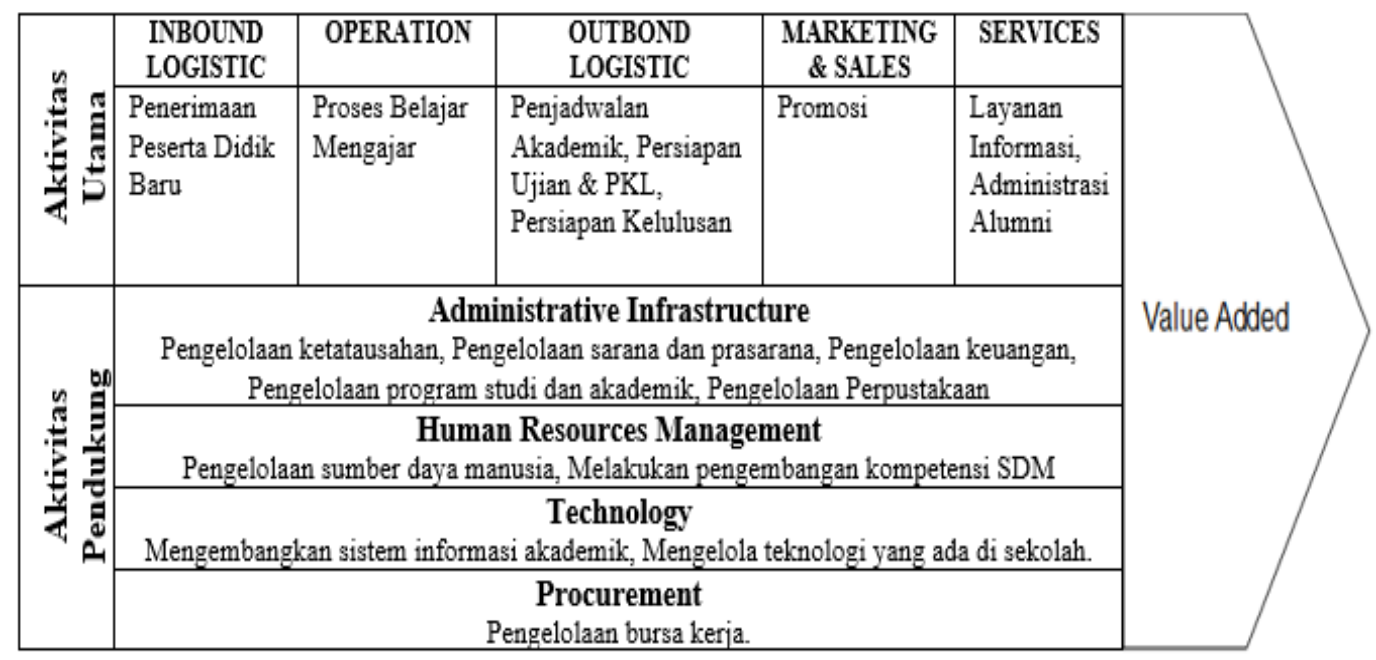

\section{Gambar 4. Value Chain Analysis}

Dari hasil analisa value chain dari SMK Bina Nusantara Ungaran, kemudian ditentukannya sistem informasi yang berpeluang untuk mendukung aktifitas proses bisnis yang ada di value chain tersebut. Berikut hasil analisa terkait kondisi sistem informasi berdasarkan value chain saat ini yang dapat dilihat di Tabel 1 dan Tabel 2.

Tabel 1. Sistem Informasi Berdasarkan Value Chain Aktifitas Utama

\begin{tabular}{llc}
\hline \multicolumn{1}{c}{ Value Chain } & \multicolumn{1}{c}{ Kegiatan } & Sistem Saat Ini \\
\hline Inbound Logistic & Melakukan pendaftaran calon siswa. & - \\
\hline Operation & Melakukan kegiatan proses belajar mengajar. & - \\
\hline Outbond Logistic & Melakukan Persiapan Ujian, PKL, dan Kelulusan & - \\
\hline Marketing \& Sales & Melakukan promosi baik offline maupun online (sosial media). & Instagram \\
\hline Services & Melakukan Layanan Informasi Sekolah dan Administrasi Alumni & - \\
\hline
\end{tabular}

Tabel 2. Sistem Informasi Berdasarkan Value Chain Aktifitas Pendukung

\begin{tabular}{llc}
\hline \multicolumn{1}{c}{ Value Chain } & \multicolumn{1}{c}{ Kegiatan } & Sistem Saat Ini \\
\hline $\begin{array}{l}\text { Administrative } \\
\text { Infrastructure }\end{array}$ & $\begin{array}{l}\text { Pengelolaan keuangan sekolah,Pengurusan administrasi } \\
\text { ketatausahaan sekolah, pengelolaan sarana dan prasarana, } \\
\text { pengelolaan program studi dan akademik }\end{array}$ & $\begin{array}{c}\text { Dapodik, SI } \\
\text { Penggajian }\end{array}$ \\
\hline $\begin{array}{l}\text { Human Resources } \\
\text { Management }\end{array}$ & $\begin{array}{l}\text { Mengelola sumber daya manusia, Melakukan pengembangan } \\
\text { kompetensi SDM. }\end{array}$ & SI Absensi \\
Technology & Mengelola dan Mengembangkan SI/TI & - \\
\hline Procurement & Pengelolaan perpustakaan & - \\
\hline
\end{tabular}

Untuk mendapatkan gambaran dari sistem informasi apa saja yang digunakan serta kontribusi dari setiap aplikasi yang digunakan untuk menunjang proses bisnis saat ini maka semua aplikasi dipetakan meggunakan model McFarlan's Strategic Grid yang dapat dilihat di Tabel 3 berikut. 
Manajemen Perencanaan Strategis Sistem Informasi Menggunakan Metode Tozer (Studi Kasus: SMK Bina Nusantara Ungaran) (Herry Sanoto)

Tabel 3. Portfolio Aplikasi Saat Ini

\begin{tabular}{ll}
\hline STRATEGIC & HIGH POTENTIAL \\
\hline- & $\bullet \quad$ SI Penggajian \\
& $\bullet \quad$ SI Absensi (Fingerprint) \\
\hline
\end{tabular}

- Instagram (Sosial Media)

- DAPODIK

\section{KEY OPERATIONAL}

SUPPORT

Dalam menentukan strategi aplikasi dan basis data yang akan digunakan pada fase ini dapat dilakukan dengan melihat tren yang berada dipasaran serta digunakan oleh banyak organisasi atau perusahaan. Hal yang menjadi perhatian adalah tren jaringan, tren aplikasi dan basis data, serta tren keamanan sistem informasi dan teknologi. Berikut strategi aplikasi yang dapat dilihat pada Tabel 4.

Tabel 4. Solusi Strategi Aplikasi dan Basis Data

\begin{tabular}{llll}
\hline Tren Jaringan & $\bullet$ & & \\
& $\bullet$ & Internet & \\
& $\bullet$ & Kabel Fiber Optik & \\
\hline Tren Aplikasi dan Basis Data & $\bullet$ & Intranet & \\
& $\bullet$ & Java & SQL Server \\
& $\bullet$ & Phyton & MySQL \\
& $\bullet$ PHP & Oracle 19c \\
& $\bullet$ ERP/SAP & \\
\hline Tren Keamanan SI/TI & $\bullet$ Authentikasi & \\
& $\bullet$ Enkripsi & \\
\hline
\end{tabular}

Dalam menentukan peluang dimulai dengan mengidentifikasikan SWOT yang dilakukan untuk mengetahui kekutan dan kelemahan dari organisasi. Setelah melakukan Analisa value chain kemudian dilanjutkan melakukan rumusan strategi SWOT terhadap aktifitas yang telah digambarkan di value chain untuk identifikasi Critical Success Factor (CSF).

Tujuan Analisa ini adalah untuk menentukan serta mengevaluasi akan kebutuhan sistem informasi bisnis dan solusi strategis aplikasi dan database. Berikut pemetaan CSF dapat dilihat pada Tabel 5.

Tabel 5. Pemetaan Critical Success Factor Analisa SWOT

\begin{tabular}{ll}
\multicolumn{1}{c}{ Peluang (Opportunity) } & \multicolumn{1}{c}{ Faktor Kesuksesan } \\
\hline $\begin{array}{l}\text { Perkembangan teknologi informasi yang semakin pesat dan modern } \\
\text { serta ketersediaan aplikasi enterprise yang dapat langsung } \\
\text { digunakan tanpa perlu mengembangkan. }\end{array}$ & $\begin{array}{l}\text { Dibangunnya sistem informasi yang } \\
\text { menunjang aktifitas bisnis sesuai } \\
\text { dengan kebutuhan. }\end{array}$ \\
\hline Lingkungan bisnis sekolah yang terus berkembang. & $\begin{array}{l}\text { Peningkatan kinerja layanan dibidang } \\
\text { Pendidikan. }\end{array}$ \\
\hline Peningkatan kualitas sekolah. & $\begin{array}{l}\text { Meningkatnya kepercayaan } \\
\text { masyarakat terhadap sekolah swasta. }\end{array}$ \\
\hline $\begin{array}{l}\text { Peningkatan jumlah lulusan yang diterima di perusahaan yang } \\
\text { bekerja sama dengan sekolah. }\end{array}$ & $\begin{array}{l}\text { Jumlah lulusan yang diterima di dunia } \\
\text { kerja meningkat. }\end{array}$ \\
\hline $\begin{array}{l}\text { Peningkatan jumlah sumber daya manusia dalam bidang } \\
\text { pendidikan. }\end{array}$ & $\begin{array}{l}\text { Tersedianya sumber daya manusia } \\
\text { yang berkompeten. }\end{array}$ \\
\hline
\end{tabular}

Berdasarkan hasil wawancara dari narasumber SMK Bina Nusantara Ungaran, maka dapat diidentifikasikan faktor SWOT. Selanjutnya Analisa tersebut dapat menjadi acuan strategi pemecahan permasalahan bisnis organisasi tersebut. Berikut hasil Analisa SWOT dapat dilihat pada Tabel 6. 
Tabel 6. Matriks Analisis SWOT

STRENGH

- Lokasi sekolah yang strategis di tengah ibukota kabupaten semarang.

- Memiliki finansial yang cukup baik sehingga dapat megembangkan bisnis perusahaan di sekolah.

- Memiliki sumber daya manusia serta saranaprasarana untuk mendukung dalam aktivitas bisnis perusahaan di sekolah.

- Memiliki jurusan yang berkompeten untuk mendukung penerapan Sistem Informasi sesuai yang dibutuhkan oleh sekolah tersebut.

\section{OPPORTUNITY}

- Perkembangan teknologi informasi yang semakin pesat dan modern serta ketersediaan aplikasi enterprise yang dapat langsung digunakan tanpa perlu mengembangkan.

- Peningkatan jumlah lulusan yang diterima di perusahaan yang bekerja sama dengan sekolah.

- Peningkatan jumlah sumber daya manusia dalam bidang pendidikan.

\section{WEAKNESS}

- Sistem informasi di sekolah belum saling terintergrasi satu sama lain sehingga mengakibatkan data-data yang dimiliki tidak tertata dengan baik.

Kebutuhan dari setiap divisi dapat ditentukan dari Analisa CSF melalui tujuan tiap devisi masing-masing. Kemudian setiap CSF dievaluasi serta disesuaikan dengan rumusan strategi yang dihasilkan dari analisis SWOT. Berikut hasil kebutuhan informasi SMK Bina Nusantara Ungaran pada aktifitas utamanya pada Tabel 7.

Tabel 7. Analisis Kebutuhan Informasi

\begin{tabular}{|c|c|c|c|}
\hline Tujuan Divisi & $C S F$ & Value Chain & Kebutuhan Informasi \\
\hline $\begin{array}{l}\text { Mempromosikan kepada } \\
\text { orang tua mengenai } \\
\text { profil sekolah. }\end{array}$ & $\begin{array}{l}\text { Meningkatnya jumlah } \\
\text { orang tua mengetahui } \\
\text { akan profil sekolah. }\end{array}$ & Marketing \& Sales & $\begin{array}{l}\text { Laporan informasi } \\
\text { PPDB. }\end{array}$ \\
\hline $\begin{array}{l}\text { Peningkatan jumlah } \\
\text { pendaftar calon peserta } \\
\text { didik baru }\end{array}$ & $\begin{array}{l}\text { Meningkatnya jumlah } \\
\text { pendaftar calon peserta } \\
\text { didik baru }\end{array}$ & Inbound Logistic & $\begin{array}{l}\text { Data calon peserta didik } \\
\text { baru, } \\
\text { Data peningkatan } \\
\text { jumlah pendaftar. }\end{array}$ \\
\hline $\begin{array}{l}\text { Menyediakan fasilitas } \\
\text { yang mendukung proses } \\
\text { bisnis dengan handal.. }\end{array}$ & $\begin{array}{l}\text { Tersediannya fasilitas } \\
\text { yang mendukung proses } \\
\text { bisnis dengan baik. }\end{array}$ & $\begin{array}{l}\text { Operation, Outbond } \\
\text { Logistic }\end{array}$ & $\begin{array}{l}\text { Informasi data PKL, } \\
\text { ujian, kelulusan dan } \\
\text { proses belajar mengajar. }\end{array}$ \\
\hline $\begin{array}{l}\text { Menyediakan informasi } \\
\text { sekolah yang akurat } \\
\text { untuk masyarakat dan } \\
\text { alumni }\end{array}$ & $\begin{array}{l}\text { Meningkatnya jumlah } \\
\text { orang akan informasi } \\
\text { sekolah. }\end{array}$ & Services & $\begin{array}{l}\text { Data informasi layanan } \\
\text { sekolah dan alumni. }\end{array}$ \\
\hline $\begin{array}{l}\text { Menyediakaan informasi } \\
\text { mengenai internal } \\
\text { sekolah. }\end{array}$ & $\begin{array}{l}\text { Tersedianya informasi } \\
\text { mengenai internal } \\
\text { sekolah guna } \\
\text { menjalankan proses } \\
\text { bisnis. }\end{array}$ & $\begin{array}{l}\text { Administrative } \\
\text { Infrastructure, Human } \\
\text { Resources Management, } \\
\text { Procurement }\end{array}$ & $\begin{array}{l}\text { Data keuangan, data } \\
\text { siswa, data pegawai, } \\
\text { data perpustakaan, data } \\
\text { bursa kerja. }\end{array}$ \\
\hline
\end{tabular}

Dalam fase ini bertujuan untuk memberikan solusi aplikasi untuk mendukung proses bisnis SMK Bina Nusantara Ungaran didapat dari analisis value chain dengan membandingkan SI/TI saat ini yang menghasilkan portofolio aplikasi future yang dapat dilihat di Tabel 8. 
Manajemen Perencanaan Strategis Sistem Informasi Menggunakan Metode Tozer (Studi Kasus: SMK Bina Nusantara Ungaran) (Herry Sanoto)

Tabel 8. Portofolio Aplikasi Future

\begin{tabular}{lcl}
\hline \multicolumn{1}{c}{ Value Chain } & Aplikasi Saat Ini & \multicolumn{1}{c}{ Aplikasi Usulan } \\
\hline Inbound Logistic & - & SI PPDB \\
\hline Operational & - & E-Learning \\
\hline Outbond Logistic & - & SI Kesiswaan \\
& & SI Prakerin \\
& & SI Kelulusan \\
\hline Marketing \& Sales & Instagram & Website Company Profile \\
\hline Services & - & SI Bursa Kerja \\
& & SI Alumni \\
\hline Administrative Infrastructure & Dapodik & SI Kurikulum \\
& SI Penggajian & SI Keuangan \\
& & SI Inventori \\
\hline Human Resources Management & SI Absensi & SI Kepegawaian \\
\hline Technology & (Fingerprint) & \\
\hline Procurement & - & SI Perpustakaan \\
\hline
\end{tabular}

SMK Bina Nusantara Ungaran

Berdasarkan usulan sistem informasi yang telah dibuat, maka akan dipetakan kedalam model McFarlan's Strategic Grid guna mengetahui skala prioritas dalam pengimplementasian oleh SMK Bina Nusantara Ungaran di kemudian hari. Berikut hasil pemetaan aplikasi dengan model McFarlan's Strategic Grid dapat dilihat pada tabel 9.

Tabel 9 Portofolio Aplikasi Usulan Model McFarlan's Strategic Grid

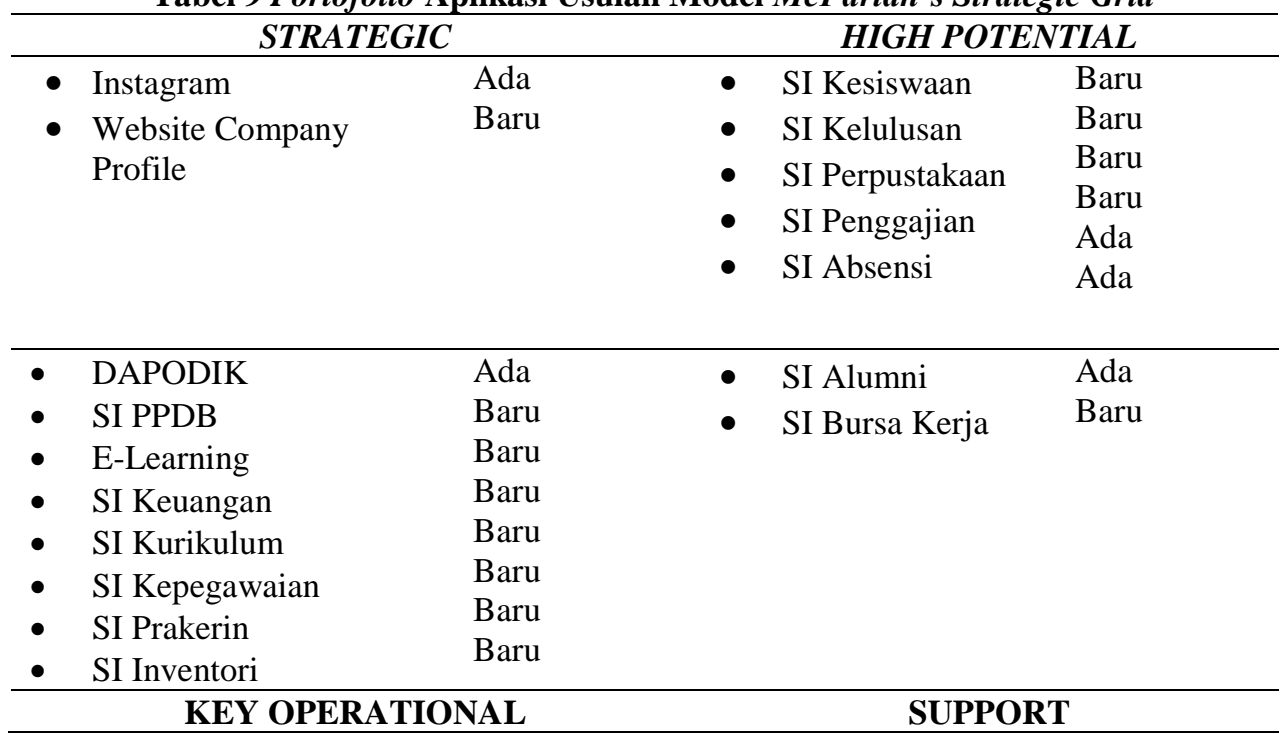

Hasil pemetaan aplikasi dengan model McFarlan's Strategic Grid menunjukkan bahwa strategi yang sudah ada terdiri dari Instagram, DAPODIK. High potential yang sudah ada terdiri dari SI Absensi, SI Alumni. Sedangkan model McFarlan's Strategic Grid yang baru terdiri dari Website Company Profile, SI PPDB, E-Learning, SI (Keuangan, Kurikulum, Kepegawaian, Prakerin, Inventori). High potential yang baru terdiri dari SI kesiswaan, SI Kelulusan, SI Perpustakaan, SI Penggajian serta SI Bursa Kerja.

\section{SIMPULAN DAN SARAN}

Berdasarkan hasil observasi serta analisa dapat disimpulkan bahwa SMK Bina Nusantara Ungaran sudah menerapkan sistem informasi, sistem tersebut cukup membantu dalam proses bisnis yang dilakukan. Namun ada beberapa devisi yang belum menerapkan sistem informasi. Dengan demikian perumusan manajemen rencana strategi SI/TI dengan metode versi tozer serta tools untuk 
mendukung analisa seperti Value Chain, Five Force, SWOT, CSF, McFarlan's Strategic Grid. Menghasilkan sebuah portofolio aplikasi untuk memberikan gambaran dalam penerapan SI/TI guna menyelaraskan strategi bisnis dan visi misi yang ingin dituju. Saran yang dapat diberikan adalah menerapkan portofolio SI/TI yang telah diusulkan kepada SMK Bina Nusantara Ungaran, sehingga diharapkan dapat memberi manfaat bagi proses bisnis sehingga dapat meningkatkan kualitas layanan dan organisasi dapat berkembang.

\section{DAFTAR PUSTAKA}

Lestari, T. A., \& Mariah, S. (2018). Strategi Pengembangan Sistem Informasi Akademik Dalam Upaya Peningkatan Mutu Pendidikan. Kelola: Jurnal Manajemen Pendidikan, 5(1), 15-23.

W. Andri. (2011). Perencanaan Strategis SI/TI Pada Perusahaan Otomotif Dengan Menggunakan Metodologi Tozer, Karya Akhir. Jakarta: Magister Teknologi Informasi, Universitas Indonesia.

W. Andri and A. Arif .(2013). Penerapan Metodologi Tozer Dalam Perencanaan Strategis SI/TI Pada Sekolah Tinggi Teknik Musik. Journal of Information Systems. 9 (2), 95-100.

Ward, J and Pepard Joe. (2002). Strategic Planning for Information System", third Edition. London: John Wiley \&Sons Ltd, England.

Tozer, E. E. (1996). Strategic Is/It Planning. Butterworth-Heinemann.

I. Windi. (2016). Perencanaan Strategis SI/TI Pada Dinas Cipta Karya, Tata Ruang Dan Kebersihan Kabupaten Kubu Raya Dengan Menggunakan Metodologi Tozer. Journal Speed - Sentra Penelitian Engineering dan Edukasi. 8 (1), 1-6. 